\title{
DISCUSSION: CHALLENGES AND RECENT DEVELOPMENTS OF FOREIGN DIRECT INVESTMENTS IN ALBANIA AND WESTERN BALKAN COUNTRIES
}

\section{Muharremi, 0 .}

Oltiana Muharremi / Stonehill College, Meehan School of Business, Department of Business Administration, 320 Washington St, North Easton, MA, 02357, United States of America. Email: omuharremi@stonehill.edu.

\begin{abstract}
Foreign direct investment (FDI) plays a crucial role in the growth and development of transitional economies and especially in countries where domestic capital is insufficient to meet the investment needs of the economy. Albania is a country applying for E.U. integration, so the country's central policies in recent years have brought about a liberalized economic framework and improved conditions for business development, attracting highly sought after FDI. This paper will provide an analysis of FDI in Albania and make a comparative analysis with the Western Balkan (W.B.) countries. The focus of the paper will also be on analyzing some of the critical elements that make these countries attractive to FDI, such as: analyzing the sectoral distribution of FDI stocks, the impact that inflows have had on the development of domestic economies, in creating jobs. FDI flows even though they have been in an upward trend, have not yet reached the desired expectations levels. W.B. countries have some very potential sectors to increase in the future and to be more attractive for FDI, such as tourism, service, transport, agriculture, industry. FDI had a positive impact on Albania's economy and in other Balkan countries. However, the region still needs to make many improvements in implementing institutional reforms, building and operating democratic institutions, improving the infrastructure. All countries need to collaborate to enhance political instability, resolve conflicts, and to focus on improvements and policies to attract potential investors. Implications for a Central European audience: This paper aims to contribute to increasing the knowledge about the opportunities and potential sectors to invest in the W.B. area. The article may make a positive contribution to the Central European businesses generally and especially to firms that are interested in investing their capital in W.B countries or scholars who currently study the effects of FDI in developing countries. There is an analysis of how public policies can further increase the attraction of FDIs, which is beneficial for public officials aspiring to absorb foreign investments in their area of oversight. The optimal geographical position of Albania and W.B. countries has played an essential role in attracting foreign investments for neighbouring countries and especially European Union countries. Central European countries such as Hungary, Austria, and Switzerland are leaders or significant investors in the region. The distance between host and recipient countries have been a dominant factor of FDI, as well as cultural and linguistic resemblances.
\end{abstract}

Keywords: FDI flows; Western Balkan; stock; impact; region

JEL Classification: F21, F20 


\section{DISCUSSION PAPER}

\section{Introduction}

In the 1990s, Albania commenced a series of economic reforms moving towards a market economy from a closed market economy. It embarked on a path of political, economic, legal, and institutional transformations of its economy. Since the late 1990s, the government has undertaken several structural reforms, such as proprietary reform, financial market reforms, price liberalization, and privatization. Almost all SMEs privatized during this period. The period has been characterized by progress in the privatization of strategic industries, especially telecommunications and the banking sector. The latter has gradually increased the number of financial services and commercial lending. Now, the country has an open economy, with a liberal financial market for investments. Albania possesses enormous economic potential stemming from its geographical location, demography, human capacities, and natural resources.

Economic growth is one of the most critical indicators in terms of a country's economic development, as well as from the essential elements for social developments. In 2008, Albania maintained favourable economic growth rates and financial sustainability, unlike other regional countries. Before the ensuing 2008 financial crisis, Albania was amongst a few countries with the most considerable economic growth in Europe, realizing real annual growth rates of $6 \%$, which helped reduce the level of poverty. Between 2002 and 2008, poverty levels in the country halved to $12.4 \%$. In 2018 , Albania's economic growth was $4 \%$, supported by strong domestic demand. Foreign investment dynamics are closely linked with two major energy projects funded by FDIs, the Trans Adriatic Pipeline (TAP) and Devoll Hydropower (Statkraft), and private spending supported by job creation and facilitation of lending terms.

Meanwhile, the main drivers of economic growth are the construction and services sectors. IMF report No 17/373 states that FDI projects involving the construction of two hydropower plants and a natural gas pipeline (14\% of GDP) will have a significant effect on the overall economic activity. Nevertheless, in Albania, there is no internal gas transmission network, and this makes the benefits of these projects, not at the expected levels. Their total investment cost of $\$ 1.5$ billion has contributed significantly to the growth of gross fixed capital formation. Also, with mainly foreign-financed investments and low national savings, concerns about the viability of investments remain high (IMF, 2017).

Table 1 | The impact of both TAP and Statkraft projects on economic growth

\begin{tabular}{clllllll}
\hline & 2014 & 2015 & 2016 & 2017 & 2018 & 2019 & 2020 \\
\hline & $\%$ GDP & & & & & \\
$\begin{array}{c}\text { FDI from TAP/Statkraft } \\
\text { of which from imports }\end{array}$ & 0.8 & 2.7 & 3.8 & 3.8 & 2.3 & 0.8 & 0 \\
& 0.5 & 1.9 & 2.7 & 2.6 & 1.5 & 0.45 & 0 \\
of which domestic expenses & 0.3 & 0.8 & 1.2 & 1.2 & 0.7 & 0.35 & 0 \\
& $\%$ & & & & & & \\
The GDP growth effect & 0.3 & 0.5 & 0.3 & 0.1 & -0.5 & -0.4 & -0.3 \\
\hline
\end{tabular}

Source: International Monetary Fund, www.imf.gov 


\section{DISCUSSION PAPER}

The country's economic growth reflects signs of fiscal consolidation by gradually reducing the budget deficit and public debt followed closely with economic stability. Albania's economy is rapidly advancing, benefiting from growing domestic demand, high FDI investments linked with the energy sector, and recovery of the E.U.'s main trading partners. Even though financial and fiscal weaknesses have diminished, low-performing loans and institutional weaknesses hamper long term investments (IMF, 2017). The main drivers of economic growth are the construction and services sectors, while the decline in energy production is having adverse effects on the industry sector. If we compare it with other Southeast European countries, it ranks at the average economic level in terms of GDP.

Figure 1 shows the trend of GDP growth as annual \% in Albania from 1988-2018.

\section{Figure 1 | GDP Growth (Annual \%)}

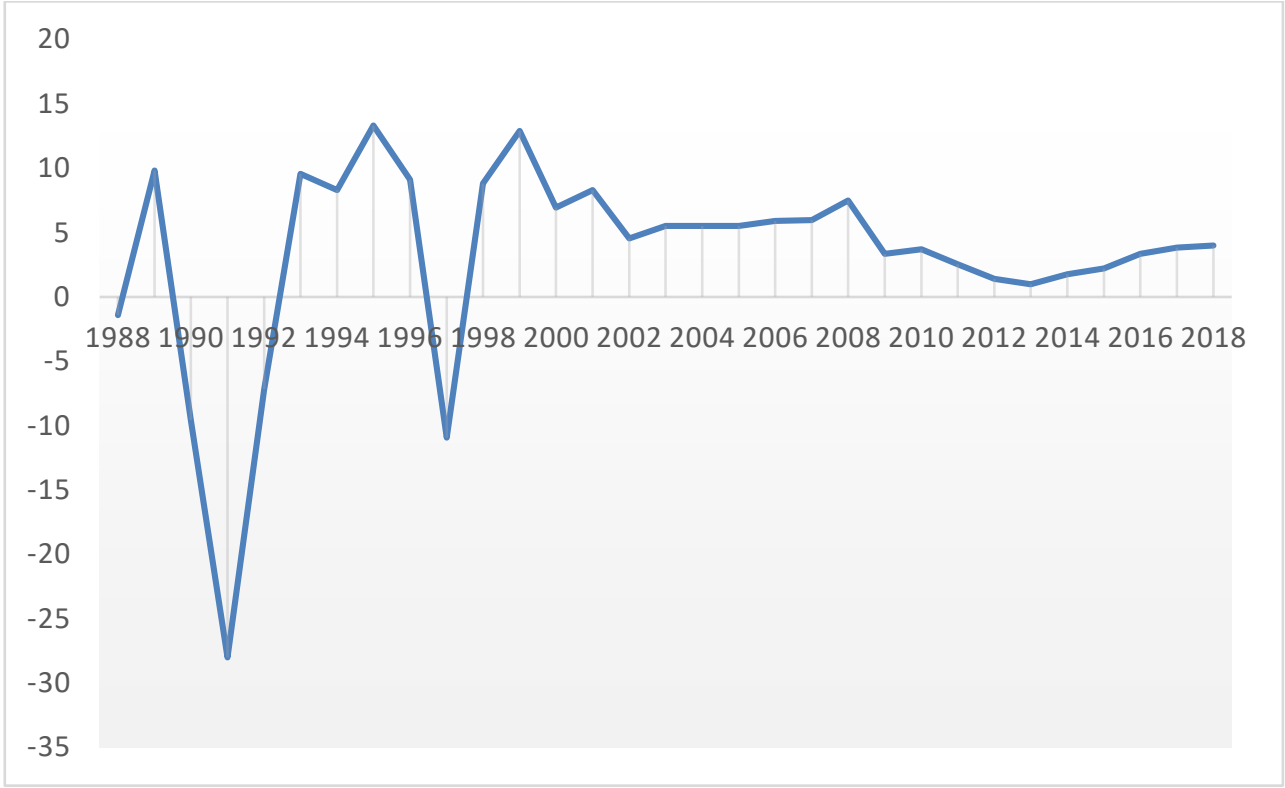

Source: World Bank, https://data.worldbank.org/country/albania

The Albanian economy has seen many ups and downs over the last decades. The most significant declines in the period analyzed in the graph are the 1990s that coincide with the advent of democracy, the economy fell significantly, by $-10 \%$ in 1990 , and a record of $-28 \%$ in 1991. Early structural reforms undertaken yielded rapid results, which were reflected in the rapid growth of the GDP. The year 1997 marked a negative moment in the Albanian economy, damaging the positive performance achieved so far. Nevertheless, very soon, the Albanian economy resumed experiencing good economic growth. In 1998-2008, Albania's economic growth went to approximately $6 \%$, at levels similar to those in the Western Balkans. It was the global financial crisis of 2007-2008 that reduced economic growth to $3.4 \%$ in 2009 . Albania was affected by the crisis in neighbouring countries, Italy, and Greece, which was followed by trade links between them. This crisis emerged with declining remittances and declining exports. Starting in 2013, Albania has improved, economic growth tripled, from 1\% 


\section{DISCUSSION PAPER}

in 2013 to $3.9 \%$ in 2017. Referring to Instat and World Bank data in 2018, the Albanian economy grew by $4 \%$ in real terms (by volume) compared to 2017 , following a $3.82 \%$ growth in 2017, compared to 2016. Recovery of it is also dedicated to large projects of foreign investors in the energy sector, which led to a significant increase in FDI. Another critical factor that has had a positive impact is the improvement of the economic situation in the European Union, Albania's main trading partners.

Albania offers an advantageous and cost-effective environment intended for doing business, an attractive incentive scheme for investors, an on-line system for business registration and tax payments, and a one-stop-shop process for commercial registration and licensing. The government has prioritized investments and potential foreign investors through liberal policies to attract as many investors as possible. In line with these policies, several reforms and legislatures have been implemented to guarantee and support foreign investment.

\section{Literature review}

The inadequacy of domestic capital is a significant problem for W. B. countries because of their limited domestic savings. Compared with E.U. countries, these countries have lower levels of income. Their main short term goals are to create suitable conditions for attracting foreign direct investment to provide new sources of financing for their economic development. Foreign capital is acknowledged as a crucial means of overcoming this deficiency (Liu and Agbola, 2014). A broader definition includes the ability of FDIs to transfer tangible and intangible assets, which include capital flows, increased competitiveness, research, and development spending, management skills, production knowledge (or expertise), and the best technology in the host country (Carbaugh, 2008). FDI also contributes to improving international competitiveness. They increase productivity levels, permitting the recipient economy to intensification exports and reinforce the balance of payments, perhaps improving international finance limitations to economic growth (Borensztein et al., 1998). Carkovic and Levine (2005) come to comparable results. They found that FDI does not have an absolute and positive outcome for economic growth. While the attestation on the connection between FDI and economic growth is unclear, several studies claim that the receiving country's absorptive capacity had a vital role in the explanation of FDI. Blomström et al. (1994) show that FDI is encouraging and substantial only for higher-income countries and that on lowerincome countries, they do not have any impact. Different scholars through their studies demonstrate that FDI inflows have positive effects on job creation, transfer of new technologies, and knowledge to host countries (Dunning, 1996; Williams, 1997; Markusen \& Venables, 1999). Žugić (2011) demonstrated that there is a direct link among capital inflows, a quicker growth of the gross domestic product, and export strategy. Nevertheless, on the other hand, some authors prove that there are adverse effects such as the creation of monopolies and oligopolies in the host markets, the creation of trade deficits, and, most of all, the removal of profits created in these countries (Agosin \& Mayer, 2000).

The W.B. is a region with a significant economic catch-up potential. These six countries, Albania, Montenegro, Bosnia and Herzegovina, North Macedonia, Kosovo, and Serbia, went through a turbulent decade accompanied by civil war, ethnic conflict, and financial crisis before considering the idea of the E.U. integration. In the 1990s, they started the transition 


\section{DISCUSSION PAPER}

and integration in a problematic situation with high political and financial uncertainty, weak institutions, structural underdevelopment, and low competitiveness, high unemployment, and an enormous trade deficit. The W. B. countries are part of the Stabilization and Association Process. Besides cross-border issues, they face significant other challenges, such as fiscal and budgetary policy instability, high unemployment, lack of adequate reforms in education, healthcare, public administration, social policies, social dialogue, competition, state aid (Rumiana, 2012). Due to these challenges, these nations are considered as fragile or ineffective democracies. There is still a lack of respect for the rule of law and high corruption. The removal of trade barriers and the creation of a joint or single market has led to increased demands for deeper integration. Domestic trade and economic exchange have positively reflected GDP growth, trade growth, and direct investment.

A majority of FDI inflows into the W. B. region takes place in the last ten years, reflecting significant policy changes geared to court foreign investors (Jirasavetakul et al., 2018). FDI over the past three decades has contributed to the region through increased business competitiveness, economic growth, job creation, technology development, and improved quality of life. FDI in the Balkans is influenced by government policies such as institutional reforms and tax incentives, the size of their economy, level of development, geographical position, the distance from the source of economies (Estrin \& Uvalic, 2015). In the 2000s, most of the FDl's focused on the banking sector, due to its privatization. There were a few investments in the manufacturing industry or agriculture, thus failing to address the longrunning structural weaknesses of the W.B. The FDI has more concentration in the trade and finance sectors. Multinational companies investing in the Balkans have contributed more to imports than to exports, as has often been the case in the Central Eastern European countries (Mencinger, 2003).

\section{Yearly performance of FDI in Albania}

FDI in the Western Balkans began to appear after 1990, specifically in Albania in 1992. Initially, the number and volume of FDI were relatively small as a result of centralized economies in these countries. Still, with time, the presence of foreign investors increased.

Instability and lack of law enforcement, domestically or regionally, have been significant barriers to foreign direct investment in Albania. Albania has made considerable progress in terms of economic liberalization and passing a proper legal framework. Due to these changes, the value of FDI measured in USD has been volatile over the last 26 years, as shown in Figure 2 below. The lowest value was in 1992, only $\$ 20$ million, while at the end of 2018, inflows were $\$ 1.3$ billion, the highest historical level in both value and specific weight to the economy, where Albania first absorbs about $10 \%$ of GDP from foreign investments.

The lowest level of FDI was in 1998 - 1999, following the 1997 civil unrest in Albania and the subsequent instability in the region, due to the Serbian ethnic wars. After the 1997 crisis, FDI declined by $50 \%$, but in the early 2000s, inflows were high. The year 2006 and later 2007 and 2008 stood out for a marked increase in FDI. This increase in investment flows due to the successful privatization of strategic industries, mainly state-owned enterprises in the field of telecommunications, banking, and energy, and a series of measures taken by the government to create industrial zones. High priority has been given to investment and 


\section{DISCUSSION PAPER}

potential foreign investors through the liberalization of investment absorption policies. In line with these policies, several reforms and laws have been implemented to guarantee and support foreign investment. Albania has implemented liberal legislation where foreign and domestic investors have the same obligations and rights. The Albanian government has given particular priority to sectors with high potential to growth, such as Renewable Energy, Mining Industry, Tourism, Industry Processing, Agriculture, Transport and Logistics, and the Information and Communication Technology sector. The rise in FDls is not yet a significant variable in terms of GDP, and their level is below the regional average. Specifically, this figure shows only the upward trend in absolute value (Zoto, 2012). The flow of FDI in Albania has followed a different and almost independent pattern from the region. The upward trend in recent years, and the highest value in 2018, are good news for Albania's economic outlook, sustainable growth, and development.

Figure 2 | FDI inflows and outflows (1992-2018)

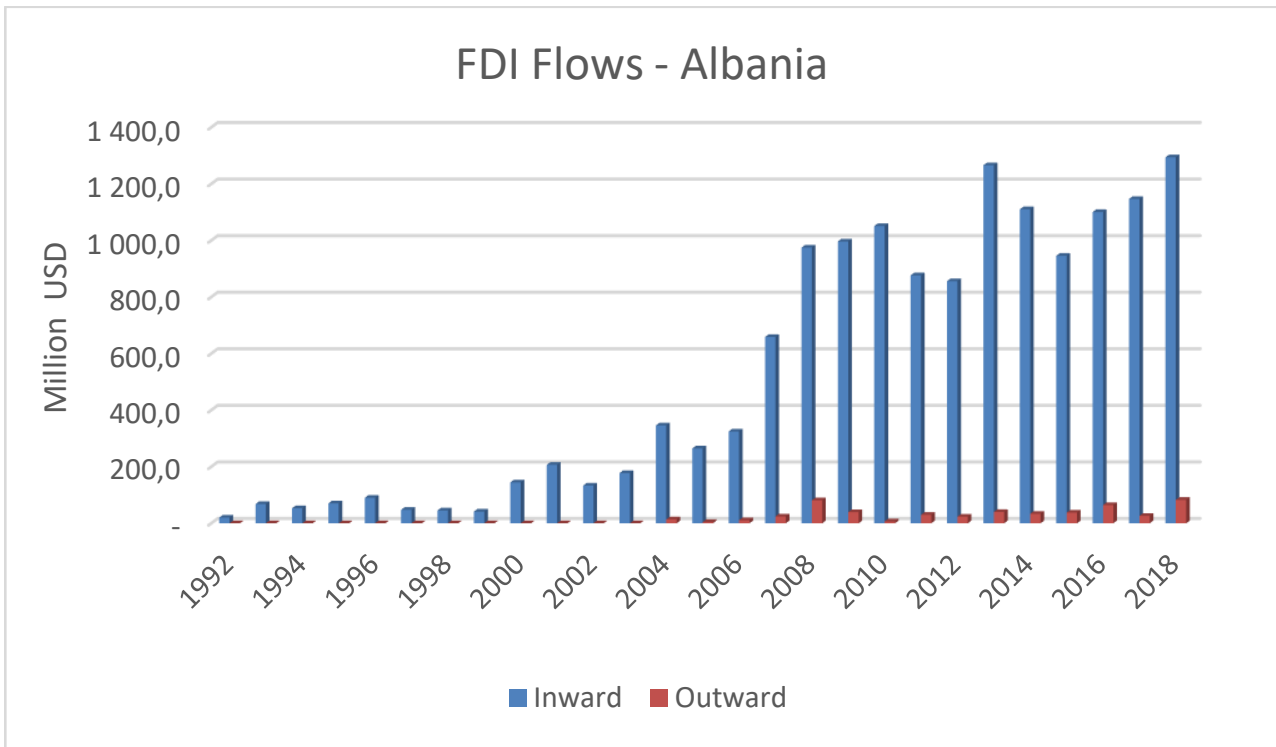

Source: UNCTAD, FDI/MNE database (www.unctad.org/fdistatistics)

For the country to have sustainable economic growth, a new economic model must be created that replaces some of the critical factors that have influenced economic expansion during the transition, such as remittances and revenue from privatization in the public sector. Albania needs to attract foreign direct investments, which contains elements of sustainable economic and social development for the country. The country shall not fear foreign direct investment outflows, as these are investments by Albanian firms in neighbouring countries such as Kosovo and North Macedonia - modest value investments representing approximately $6 \%$ of FDI inflows.

Bank of Albania data shows that in the period January- September 2019, FDI inflows were \$ 898 million, and there is an increase of $7.3 \%$ from the previous year. 


\subsection{FDI Stock in Albania, by country of origin}

At the end of 2017, E.U. countries constituted the primary source of FDI stock in Albania, with a rate of $57 \%$. Bank of Albania's most recent data shows that the central investing countries with the highest FDI stock are Italy and the Netherlands, with $18.8 \%$ and $12.8 \%$, respectively. Out of the other countries, Switzerland (from Trans Adriatic Pipeline investment) has the most extensive stock at $13.8 \%$, followed by Canada (Hydro Power Plants investments) with $13.7 \%$. The cumulative FDI stock in Albania is still small and far from regional indicators. During the last two decades, it is appraised that about $\$ 11.85$ billion of FDI has entered Albania. The value of Cumulative Income Stock for 2018 is $\$ 7.902$ million, representing nearly $52 \%$ of GDP (United Nations, 2019).

The reinvestment of profits from foreign enterprises boosts the economy, so the "scale effect" starts and works positively for the country absorbing FDIs. In countries with long FDI experience, reinvestment of their profits reaches up to $30 \%-40 \%$ of annual investments. It is required, among other things, a more specific fiscal and tax policy. The "Retained Earnings/Reinvestment" ratio in Albania skews sharply from the "retained and transferred earnings" abroad in FDI countries of origin. Foreign investment is considered as one of the primary sources of employment. In 2017, international and joint ventures employed $18.7 \%$ of the total workforce. Analysis of the intersection of employment data with foreign investment shows a paradoxical result. Foreign capital invested in the Albanian economy has not generated high employment, not enough to mitigate the adverse effects of closing public owned enterprises.

Table 2 | FDI Stock by country (million EUR)

\begin{tabular}{l|l|l|l|l}
\hline FDI & $\mathbf{2 0 1 4}$ & $\mathbf{2 0 1 5}$ & $\mathbf{2 0 1 6}$ & $\mathbf{2 0 1 7}$ \\
\hline Stock Total & $4,565.9$ & $4,981.7$ & $5,677.3$ & $6,453.5$ \\
EU-28 & $2,970.0$ & $3,289.3$ & $3,365.8$ & $3,672.2$ \\
$\quad$ Austria & 358.4 & 386.9 & 359.6 & 447.5 \\
$\quad$ Great Britain & 20.8 & 23.8 & 38.4 & 51.2 \\
$\quad$ Germany & 129.5 & 137.2 & 122.7 & 111.5 \\
Greece & $1,179.6$ & $1,204.8$ & $1,232.6$ & $1,216.8$ \\
Italy & 523.7 & 547.5 & 604.4 & 610.1 \\
Holland & 506.0 & 702.8 & 718.0 & 826.3 \\
Other -EU & 252.1 & 286.4 & 290.1 & 408.3 \\
Switzerland & 79.4 & 120.6 & 550.1 & 893.7 \\
Canada & 725.3 & 691.4 & 739.5 & 883.8 \\
USA & 88.4 & 94.5 & 80.8 & 79.1 \\
Others & 702.8 & 785.9 & 941.0 & 924.7 \\
\hline
\end{tabular}

Source: Bank of Albania

\subsection{An analysis of FDls in Albania based on business activity}

Foreign investors penetrate a country in the form of investments on new businesses or crossborder mergers and acquisitions. FDI stocks by activity have experienced constant fluctuations over recent years. In Albania, the distribution by sectors of FDI has followed the world trend. A significant portion of FDI is concentrated in the service sector. FDIs that have entered Albania so far have mainly focused on providing services for the domestic market. FDI, oriented primarily for the service sector, has helped increase the performance of the 


\section{DISCUSSION PAPER}

service sector in recent years. This sector's contribution to the GDP's growth has been growing and many times higher than the contribution of the manufacturing industry. The FDI stock of "Information and Communication" has recorded negative values in the last years, therefore not attracting foreign investors to participate in this sector. There were huge investments in the mining and energy sector, some of which also provided exports in the past. Some of the investments are in crude oil, infrastructure, real estate, construction, telecommunications, and manufacturing sectors.

Figure 3 | FDI stock by the business sector for every trimester (million Euro)

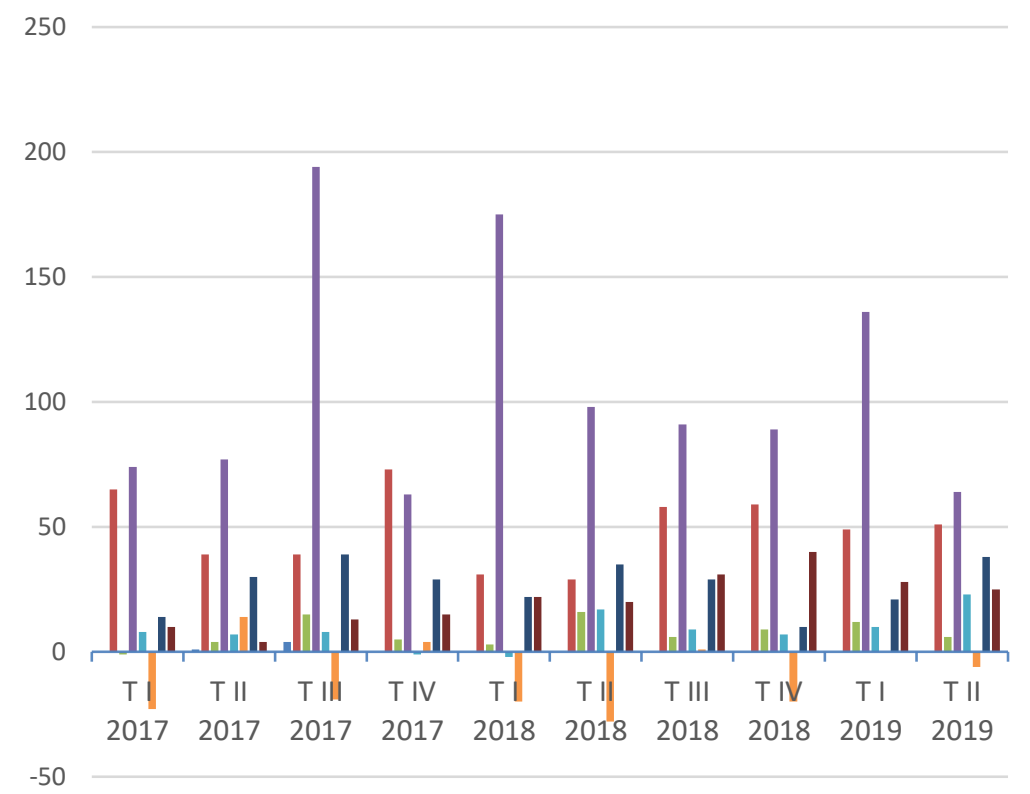

Agriculture,
forestry and
fishing
Extractive
industry
Manufacturing
industry
Electricity, gas,
and water
supply
Building

Information
and
communication
Financial and
insurance
activities
Real estate
activities

Source: Bank of Albania

The most critical and high potential areas for future investments are:

- Energy: The country seeks to develop a long-term strategy for building a technically and financially viable operational and energy-efficient power system capable of meeting domestic demand and exporting energy.

- Renewable Energy: Water resources are among the most critical natural resources in Albania

- Mining industry: The country has natural resources: chromium, coal, nickel, copper, oil and natural gas

- Manufacturing industry: It has mainly absorbed investments of Italian and Greek SMEs in food processing, textiles, shoe production

- Tourism: Geographical location suitable for the development of mountain, coastal, and cultural tourism 
- Agriculture and food processing: The country has great potential in achieving a highly competitive agro-processing industry

- Telecommunication: in the early 2000 s the privatization of this sector had played a leading role in attracting a lot of foreign investments

- Financial Services Sector: This is the leading industry in FDI due to the privatization of public entities.

\section{Comparative analysis between regional countries}

In the early 1990s, due to the local political instabilities', as well as the labor force low competitiveness, inflows into the W.B. region were low. In 1995, FDI inflows in the region accounted for approximately $\$ 4$ billion. In the later years, the inflows of foreign investment improved a little. Moreover, the foreign direct investment inflows within the regional countries were unbalanced. In 2000, North Macedonia received $\$ 215$ million by far the most out of the other countries. Serbia absorbed a relatively low inflow with only $9 \%$, mainly as a result of the war with Kosovo in 1999.

W. B. countries witnessed an increase in foreign inflows in the 2000s. Figure 4 below compiles data from the World Bank, which illustrates the expansion of net inflows from 20002018. Political stability and improvement of economic factors in the region are stimulated by foreign direct investment from E.U. countries but also from other countries such as Russia, Canada, and Turkey. Serbia has been the leading country with the highest level of FDI inflows, followed by Albania. North Macedonia, which led in the 1990s with FDIs, had the lowest levels in the 2000s. All the W.B. nations experienced decreases in FDI inflows during the global financial crisis (2007-2008) except Albania, which still registered an incremental increase. In 2018 total FDI inflows within the region were mainly stabilized. Serbia continues to receive the most substantial portion of FDI in the region, reaching nearly $\$ 2.9$ billion in 2018 , followed by Albania with $\$ 1.29$ billion.

Figure 4 | FDI, net inflows - Western Balkan 1992-2018 (million USD)

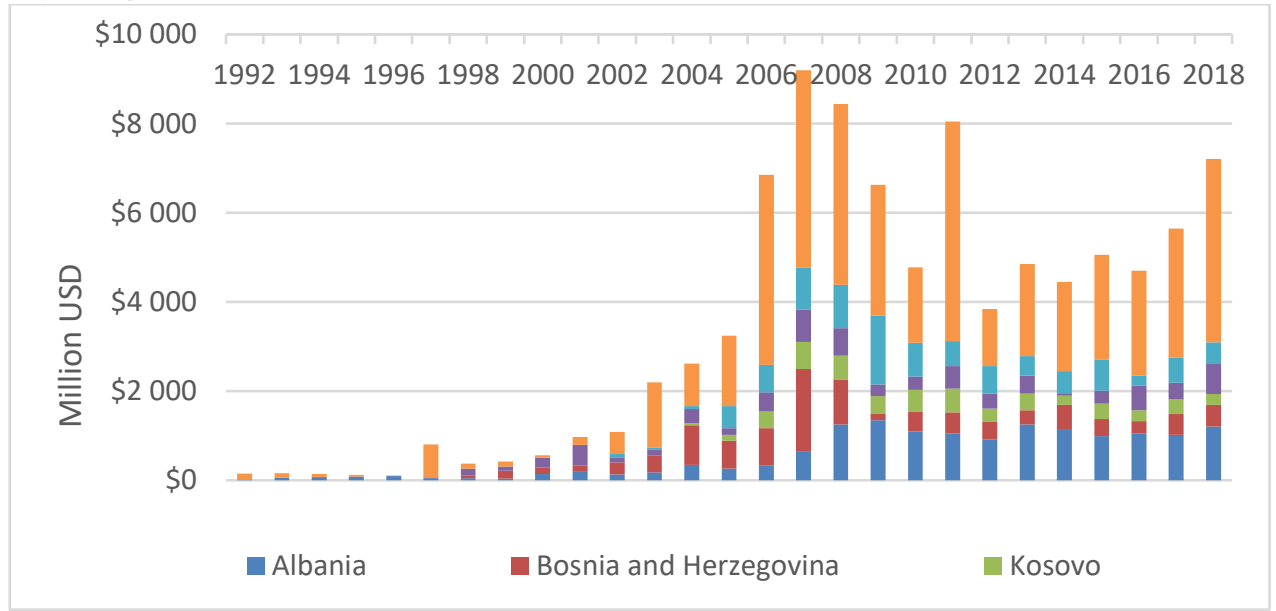

Source: World Bank Data 


\section{DISCUSSION PAPER}

FDI net inflow in North Macedonia and Serbia declined recently in 2019. However, for the entire region, there are proper expectations for the inflow in 2019; the levels should be higher than the average of the last five years. In Bosnia and Herzegovina, FDI can contribute to financing approximately $50 \%$ of the current account deficit (CAD), while in Albania and North Macedonia, it may be higher than the total level of CAD.

Figure 5 | FDI Inward Stock

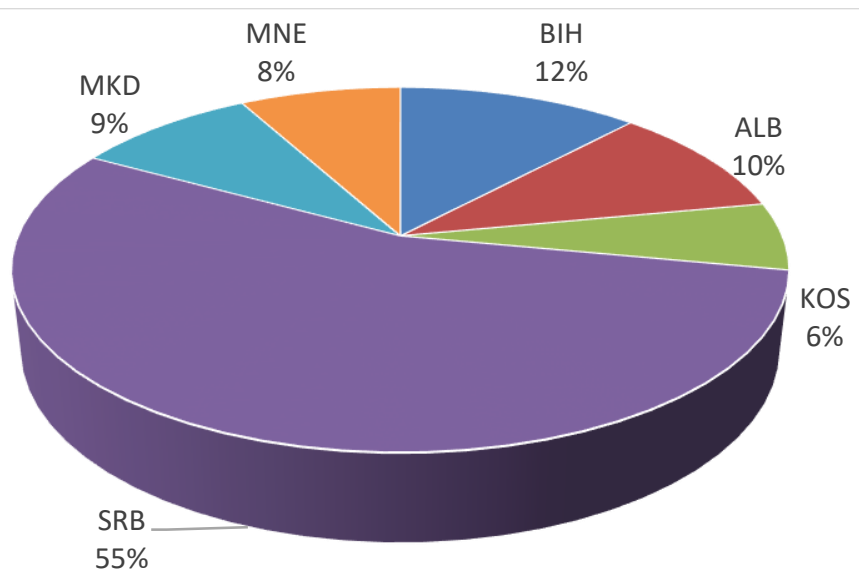

Source: WIIW database

Figure 5 shows the FDI inward stock in W. B. countries. The highest percentage of inward stock, $55 \%$ is for Serbia, followed by Bosnia and Hercegovina with $12 \%$. The lowest level is in Kosovo, only $6 \%$ of the inward stock.

Figure 6 | Service FDI Inward Stock

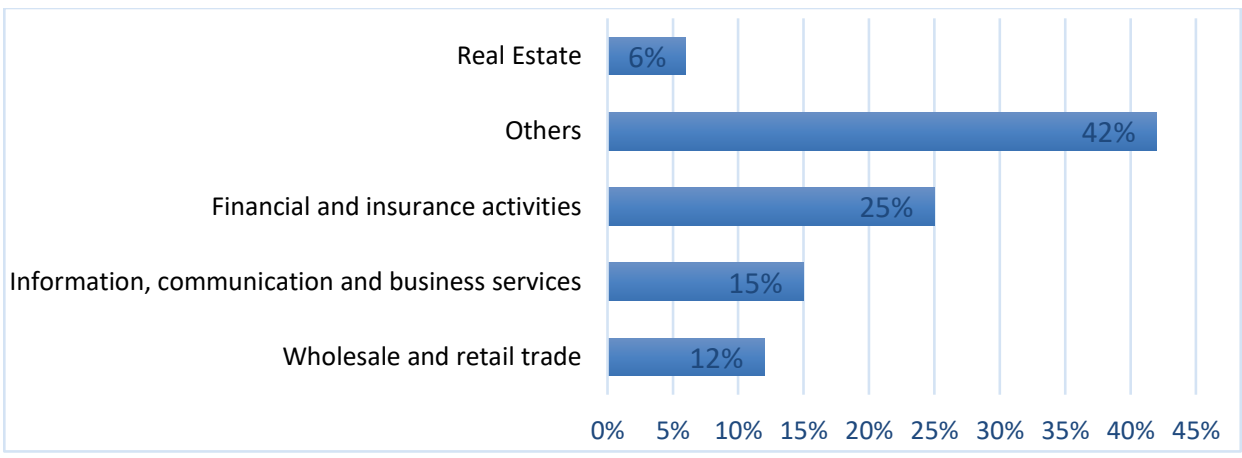

Source: WIIW database

Economies in the W. B. region tend to be very diverse, rather than relying on one or more sectors, and therefore offer a wide range of opportunities for investors. A diversified economy is also one that allows the development of human capital to expand in many ways. The service sector dominates foreign investment in almost all the countries of the W.B. region. The highest percentage of FDI has gone into non-tradable services. After the 1990s, all 


\section{DISCUSSION PAPER}

countries in the region went through a process of structuring the banking system, with stateowned banks and later financial sector privatizations primarily by foreign banks. For countries in transition in the early stages of developing a market economy, the growth of the private banking sector precedes the development of the financial sector. The presence of wellestablished foreign banks in a developing country is a prerequisite for generating FDI in other sectors of the host economy. The W.B. States' success in luring in FDI during the 2000s was probably linked to the circumstance that privatization of critical economic sectors in the new E.U. member states was already finalized. The foreign investors' positive experience with those countries, made them change, and turn the focus on new markets that were being privatized (Botric, 2010).

The category "domestic trade, transport and storage, accommodation and food services" is, on average, the largest sector of W. B. economies, accounting for $18 \%$ of the total of gross value added, in Albania and Serbia at the level of $27 \%$ in Montenegro. While the wholesale and retail sub-sector accounts for about $15 \%$ of the region's economies, the importance of tourism-dependent accommodation and food services in Montenegro $8 \%$ is what distinguishes this country from the rest of the region. The role of industry is particularly important in Serbia and, to a lesser extent, in Bosnia and Herzegovina and Kosovo.

Foreign investors from E.U. countries make the top ten list of investors in virtually all W.B. countries. In terms of geographical distribution, the structure of foreign capital of FDI prevails from Italy and Greece for Albania and Russia for Montenegro. E.U. countries are the most prominent investors in North Macedonia. Austria is a leading investor nation in Bosnia and Herzegovina; Hungary, Great Britain, Canada, Italy, and the Netherlands are also significant investors in the region. Estrin \& Uvalic (2015) had found that among dominant factors, the distance between host and recipient countries may have been a significant determining factor of FDI, as well as cultural and linguistic resemblances. Kathuria et al. (2008) show that intraregional FDI flows are typically focused in a few sectors (e.g., investment, finance, trade, and energy). For example, Slovenia, Croatia, Serbia are frequently significant investors in the region, so the investment tendency appears to spread south-eastwards regularly.

\subsection{Impact of FDI Inflows}

This section will examine the economic impact that FDI inflows have on the development of W. B. countries. There will be an analysis of the impact of FDI has on gross fixed capital formation, economic growth, and job creation in the host countries. Kalotay (2010) shows that in the transition region, FDI to the gross fixed capital formation ratio has tended to be higher than the world average and has enlarged over time. The data analyzed shows that FDI contributed meaningfully to the formation of fixed capital in all W. B. countries from 2003 nowadays. To analyze the FDI inflows in gross fixed capital formation are taken three years of data, 2003, 2010, and 2016. Since 2003, FDI has significantly contributed to the gross capital formation with an increasing trend. In 2010 Montenegro witnessed the highest ratio of $85 \%$. The data from 2016 show the highest proportion is in Serbia, with over $34 \%$ and the lowest rate in Bosnia and Hercegovina at 10\%. Comparing with 2003, in 2010, Montenegro registered the highest increase within this period, but in 2016 the country witnessed the lowest ratio. 


\section{DISCUSSION PAPER}

Figure 7 below shows the FDI inflows as a percentage of gross fixed capital formation for Albania, B \& H, Montenegro, and Serbia; there is no available data for North Macedonia and Kosovo.

Figure 7 | FDI inflows as a \% of gross fixed capital formation (W.B. Countries)

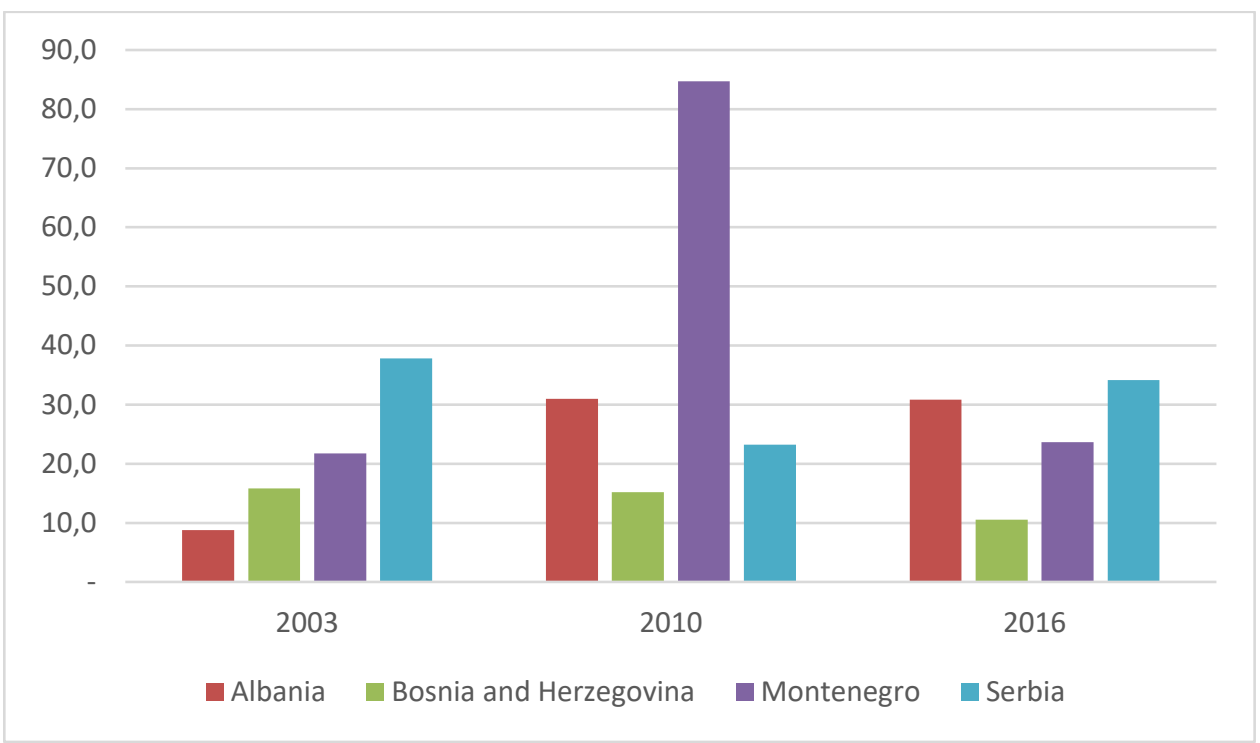

Source: OUNCTAD, FDI/MNE database (www.unctad.org/fdistatistics)

One of the most critical indicators of foreign capital penetration in an economy is FDI inflow as a percentage of GDP. This indicator also demonstrates the notable impact of FDI in the GDP of all the W.B. countries. The ratio of foreign capital to gross capital formation had the lowest value of $0.54 \%$ for North Macedonia in 2014 and the highest value in Montenegro (over 80\%) in 2010. In 2018 the highest value was for Montenegro (8.9\%), followed by Serbia $(8.13 \%)$. FDI and foreign loans were subjective regarding the service sector and consumption rather than investment. In Albania, the international companies employ many workers in the manufacturing industries, in the productions of clothing and leather goods, as well as industries that use a large amount of capital production of non-metallic minerals and metalbased products. In the region, the FDI had not a significant impact on production and export growth. From 2003 to 2007, the structure of capital inflows enhanced as the share of foreign direct investment in capital inflows raised. The reason behind this was that a complex privatization agreement was finalized with success, and some countries initiated to develop some green energy investments. The W.B. countries' total GDP growth rose to a projected $3.9 \%$ in 2018 (Albania, North Macedonia, and Serbia experienced higher levels of growth than in 2017). GDP growth in Montenegro continued unchanged between 2017 and 2018, whereas Bosnia and Herzegovina were the only nation to notice a decline.

From the early 2000s and onwards, FDI does not appear to have created many new employment opportunities in the region. Regardless of FDI increase, mainly from 2003 


\section{DISCUSSION PAPER}

onwards, employment rates in the region have typically been much lower than the E.U. average, and since 2002 have been stagnating or declining (Estrin \& Uvalic, 2013).

Figure 8 | FDI net inflows as \% of GDP in the W.B. countries, 2003-2018

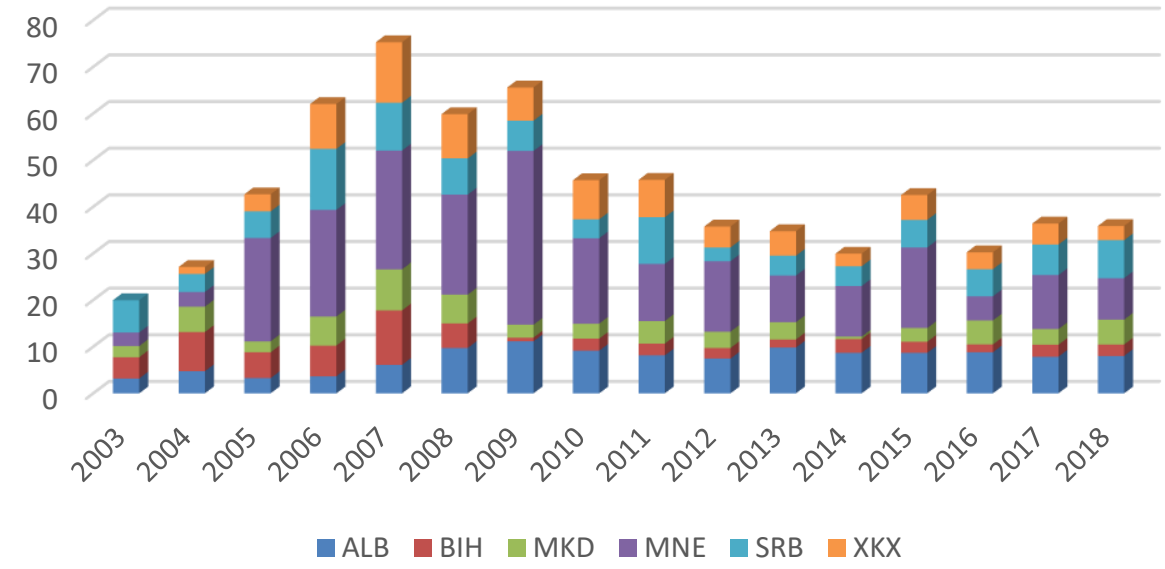

Source: Author's elaborations according to World Bank data

Labour was and still is a crucial attraction for foreign investors. Favourable wage costs were amongst the five factors investors considered on strategic investments and relocation opportunities. A decade later, labour remains essential, not so much so for costs but quality, productivity, and qualification. In terms of employment, there is an unfair relationship between several foreign companies, their turnover, and added value and the workforces employed in them. The labour market condition is still substandard. Almost all countries have a high level of unemployment and a high rate of an informal economy. In 2018 in most W. B. states, the unemployment rate was in the historical low values, but they are still higher if we compare with the E.U. countries. Unemployment rates fluctuated from about $12 \%$ in Serbia and Albania to $29 \%$ in Kosovo (Word Bank Report, 2019a,b).

\subsection{Doing Business 2019 - World Bank report}

The report Doing Business 2019 (World Bank, 2019a) analyzes business regulations for local firms in 190 countries. In the W. B. countries, North Macedonia holds the best position, ranking $10^{\text {th }}$, followed by Kosovo in $44^{\text {th }}$ place. Kosovo has experienced the highest growth, making significant improvements in major business areas such as ease of applying for construction permits, paying taxes, and simplified border controls with Albania. Bosnia and Herzegovina rank $89^{\text {th }}$, making it the last country in the region. In respect to hedging against credit, Montenegro, Kosovo, and North Macedonia rank $12^{\text {th }}$. The borrowing indicator reflects improved banking system efficiency in these countries following privatization and foreign investment. The 2019 report also summarizes that banking supervision was strengthened in several Balkan countries. 
Table 3 | Doing Business 2019

\begin{tabular}{l|l|l|l|l|l|l}
\hline & Albania & $\begin{array}{l}\text { Bosnia and } \\
\text { Herzegovina }\end{array}$ & $\begin{array}{l}\text { North } \\
\text { Macedonia }\end{array}$ & Montenegro & Serbia & Kosovo \\
\hline $\begin{array}{l}\text { Ease of Doing Business } \\
\text { Rank }\end{array}$ & $\mathbf{6 3}$ & $\mathbf{8 9}$ & $\mathbf{1 0}$ & $\mathbf{5 0}$ & $\mathbf{4 8}$ & $\mathbf{4 4}$ \\
Starting a business & 50 & 183 & 47 & 90 & 40 & 13 \\
$\begin{array}{l}\text { Dealing with construction } \\
\text { permits }\end{array}$ & 151 & 167 & 13 & 75 & 11 & 100 \\
Getting electricity & 140 & 130 & 57 & 134 & 104 & 113 \\
Registering property & 98 & 99 & 46 & 76 & 55 & 37 \\
Getting credit & 44 & 60 & 12 & 12 & 60 & 12 \\
Protecting minority investors & 26 & 72 & 7 & 57 & 83 & 95 \\
Paying taxes & 122 & 139 & 31 & 68 & 79 & 44 \\
Trading across borders & 24 & 37 & 29 & 47 & 23 & 51 \\
Enforcing contracts & 98 & 75 & 37 & 44 & 65 & 50 \\
Resolving Insolvency & 39 & 37 & 30 & 43 & 49 & 50 \\
\hline
\end{tabular}

Source: The rankings are from the Doing Business 2009 report, Training for Reform. Data in Doing Business 2019 are current as of May 1, 2018.

W.B. countries offer numerous economic inducements to investors, as well as tax-free holidays, VAT exclusions for imports, assets assistance, duty-free import, and labor training. Fiscal reforms continued, with almost all countries performing well in their tax collection and improving public investment procedures. The region has made numerous improvements to the business environment. Still, the reform agenda remains large and remains a significant challenge ahead. To increase the region's export competitiveness are essential fiscal management reforms. Reforms should be done to strengthen government institutions that implement and protects the rule of law and fight the bureaucracy. These reforms as a whole would support unlock more stable, equitable, and sustainable growth, guaranteeing faster convergence with E.U. income levels (World Bank, 2019c).

\section{Conclusions}

Albania has had positive effects from foreign direct investments in the economy. FDI can be used as a powerful growth driver for the local economy by increasing capital inflow in the country, introducing new technologies, increasing productivity, improving environmental conditions, creating jobs, raising living standards. Albania still has high and underdeveloped potential in attracting FDls in many sectors such as manufacturing, agro-processing, agriculture, technology, tourism. Numerous FDIs have, in recent years, been offered to Albania's power system. The purpose is to create a viable system operationally, technically, and financially capable of meeting the increasing demand for electricity within the country, of transforming it Albania in the long run, from an electricity importing country to an exporting country. One of the most important sectors with high potential for growth in agriculture and agro-industry, which requires investments to develop and increase market competitiveness. At the same time, they should coordinate their activity to process agricultural products domestically and, in addition to meeting the demands of the internal market, initially aim to 


\section{DISCUSSION PAPER}

increase exports to the region, with a further aim of expanding to the international market. A massive problem in this sector remains the unresolved land ownership issue.

The W.B. region in the past 20 years has seen an increase in FDI. Capital inflows from foreign investors have been predominantly focused on the non-tradable sector and consumption. The rise of FDI inflows practically year after year, during this period, is related to the strategic sector's privatization. The privatization process has been an essential catalyst for attracting FDI. However, to maximize the profits of foreign investments, the composition of foreign capital should be focused more on entities that increase exports, improve technology, raise productivity growth, and employment. Among the drivers of foreign investment in the region have been policies that facilitate trade, geographical position, favorable fiscal policies, increased economic and political stability, labor market flexibility, and more.

Some of the negative factors that have prevented the W. B. region from becoming an attractive destination for foreign investors are the delays and slowness in implementing institutional reforms, building and operating democratic institutions, high corruption, political instability, and several other issues. Although these countries are undertaking ongoing changes to integrate into the E.U., they first need to complete necessary economic reforms, adopt better commercial policies, and ensure long term political stability while also focusing on E.U. integration. Progress in these areas will automatically mean more capital inflows in the region from foreign investors.

\section{References}

Agosin, M., \& Machado, R. (2005). Foreign Investment in Developing Countries: Does it Crowd in Domestic Investment? Oxford Development Studies, 33(2), 149-162. https://doi.org/10.1080/13600810500137749.

Blomström, M., Lipsey, R. E., \& Zejan, M. (1994). What explains developing country growth? In Baumol, W., Nelson, R., and Wolff, E. (eds.), Convergence and Productivity: Gross-National Studies and Historical Evidence, 246-262, Oxford: Oxford University Press.

Botric, V. (2010). Foreign direct investment in the western Balkans: Privatization, institutional change, and banking sector dominance. Ekonomski Anali, 55(187), 7-30. https://doi.org/10.2298/eka1087007b.

Borensztein, E., De Gregorio, J., \& Lee, J. (1995). How Does Foreign Direct Investment Affect Economic Growth? NBER Working Paper Series. https://doi.org/10.3386/w5057.

Carbaugh, R. J. (2008). International Economics. (12th ed.). Cengage Learning.

Carkovic, M. \& Levine, R. (2005). Does foreign direct investment accelerate economic growth? In Graham E. M., Moran, T. H., and Blomström, M. (eds.), Does Foreign Direct Investment Promote Development: New Methods, Outcomes, and Policy Approaches, 195-220, Washington, D.C.: Institute for International Economics Press.

Dunning, J. (1992). Transatlantic Foreign Direct Investment and The European Economic Community. International Economic Journal, 6(1), 59-82. https://doi.org/10.1080/10168739200080004.

Estrin, S., \& Uvalic, M. (2016). Foreign Direct Investment in the Western Balkans: What Role Has it Played During Transition? Comparative Economic Studies, 58(3), 455-483. https://doi.org/10.1057/ces.2016.10.

Estrin, S., \& Uvalic, M. (2014). FDI into transition economies. Economics of Transition, 22(2), 281-312. https://doi.org/10.1111/ecot.12040. 


\section{DISCUSSION PAPER}

IMF (2017). Country Report No. 17/373, Albania. Retrieved from https://www.imf.org/en/Publications/CR/Issues/2017/12/13/Albania-2017-Article-IV-ConsultationPress-Release-Staff-Report-and-Statement-by-the-45468.

Jirasavetakul, La-Bhus F. \& Rahman, J. (2018). Foreign Direct Investment in New Member States of the E.U. and Western Balkans: Taking Stock and Assessing Prospects, IMF Working Paper 18/187. International Monetary Fund, Washington, DC.

Liu, W., \& Agbola, F. (2014). Regional analysis of the impact of inward foreign direct investment on economic growth in the Chinese electronic industry. Applied Economics, 46(22), 2576-2592. https://doi.org/10.1080/00036846.2014.907478.

Kalotay, K. (2010). Patterns of inward FDI in economies in transition. Eastern Journal of European Studies, Centre for European Studies, Alexandru Ioan Cuza University, vol. 1, 55-76 December.

Markusen, J., \& Venables, A. (1999). Foreign direct investment as a catalyst for industrial development. European Economic Review, 43(2), 335-356. https://doi.org/10.1016/s0014-2921(98)00048-8.

Mencinger, J. (2003). Does Foreign Direct Investment Always Enhance Economic Growth?. Kyklos, 56(4), 491508. https://doi.org/10.1046/j.0023-5962.2003.00235.x.

OECD, (2016C), competitiveness in southeast Europe - A Policy Outlook, OECD Publishing, Paris. http://dx.doi.org/10.1787/9789264250529-en.

Rumiana, J. (2012). The Impact of the Crisis on the E.U. Perspective of the Western Balkans, Center for European Studies (CES). Belgium, from https://martenscentre.eu/sites/default/files/publicationfiles/the-impact-of-the-crisis-western-balkans-web.pdf.

United Nations. (2019). World Investment Report 2019: Special Economic Zones. New York.

Williams, D. (1997). Strategies of multinational enterprises and the development of the Central and Eastern European economies. European Business Review, 97(3), 134-138. https://doi.org/10.1108/09555349710167549.

World Bank (2017). "Global Investment Competitiveness Report 2017/2018: Foreign Investor Perspectives and Policy Implications," Washington DC, World Bank.

World Bank (2019a). Doing Business Report, Training for Reform. Retrieved from https://www.doingbusiness.org/en/doingbusiness.

World Bank (2019b). Western Balkans Labor Market Trends. Retrieved from https://www.worldbank.org/en/region/eca/publication/labor-trends-in-wb.

World Bank (2019c), Western Balkans Regular Economic Report No.16 Rising Uncertainties. Retrieved from https://www.worldbank.org/en/region/eca/publication/western-balkans-regular-economic-report.

Zoto, O. (2012). Dissertation: Foreign direct investment in Albania: Analysis of Effects, Policies, and Link to Economic Growth.

Žugić, J. (2011). Foreign Direct Investment and Global Economic Crisis in the Western Balkans European Perspectives. Journal on European Perspectives of the Western Balkans, 3(1-4), 69-90. Retrieved from http://stara.cep.si/dokumenti/Zugic.pdf.

The discussion paper didn't pass the full-fledged review process. | Received: October 28, 2019; Accepted: April 7, 2020; Published: September 1, 2020. 